УДК 371.132

DOI: $10.37026 / 2520-6427-2021-107-3-81-85$
Наталя КОШЕЛЕВА,

кандидат педагогічних наук, доиент, доцент кафедри психології

Горлівського інституту іноземних мов ДВНЗ «Донбаський державний педагогічний університет»,

м. Бахмут, Україна

ORCID:0000-0002-0380-3242

e-mail:cosheleva.natali@ukr.net

\title{
РОЗРОБЛЕННЯ КРИТЕРІАЛЬНОГО АПАРАТУ ОЦІНЮВАННЯ ПСИХОЛОГІЧНОЇ КОМПЕТЕНТНОСТІ МАЙБУТНІХ ВИКЛАДАЧІВ УКРАЇНСЬКОЇ МОВИ ТА ЛІТЕРАТУРИ
}

\begin{abstract}
Анотація. Стаття є частиною дослідження, присвяченого актуальній проблемі формування психологічної компетентності майбутніх викладачів украӥнської мови та літератури. Обтрунтовано необхідність иілеспрямованого формування означеноі компетентності у майбутніх учителів-філологів у процесі підготовки в закладах вищої освіти. Проаналізовано різні підходи науковиів до поняття «психологічна компетентність фахівців», а також запропоновано авторський підхід до сутності психологічноі компетентності майбутніх викладачів украӥнськоі мови та літератури. Узагальнено наукові підходи до проблеми оцінювання сформованості різних аспектів компетентності майбутніх фахівців-філологів. Ірунтуючись на результатах власних попередніх досліджень стосовно визначення змісту і структури психологічної компетентності, сформульовано пропозиції щзодо розроблення критеріального апарату
\end{abstract}

оцінювання ї̈ сформованості. Відповідно до структурних компонентів психологічної компетентності майбутніх викладачів украӥнської мови та літератури запропоновано використовувати такі критерії, як мотиваційно-особистісний, когнітивний, практичний та аутопсихологічний. Докладно схарактеризовано показники досліджуваної компетентності, наявність яких свідчить про сформованість ї̈ компонентів у майбутніх учителів. Зважаючи на розроблені критерії та показники виокремлено й обтрунтовано високий, середній та низький рівні психологічної компетентності майбутніх викладачів украйнської мови та літератури.

Ключові слова: професійна педагогічна компетентність, психологічна компетентність, майбутні викладачі украӥнської мови та літератури, критеріальний апарат дослідження, критерії, показники та рівні психологічної компетентності.

\author{
Natalia KOSHELEVA, \\ Candidate of Pedagogical Sciences, \\ Associate Professor, \\ Department of Psychology, \\ Horlivka Institute for Foreign Languages of the \\ Donbas State Pedagogical University, \\ Bakhmut, Ukraine \\ ORCID:0000-0002-0380-3242 \\ e-mail: cosheleva.natali@ukr.net
}

\section{DEVELOPMENT OF CRITERIAL APPARATUS FOR PSYCHOLOGICAL COMPETENCE EVALUATION OF FUTURE UKRAINIAN LANGUAGE AND LITERATURE TEACHERS}

\begin{abstract}
The article is a part of the research dedicated to the relevant problem of psychological competence formation of future Ukrainian language and literature teachers. In previous works the analysis of scientific approaches to the definition of professional competence of future teachers-philologists was carried out. The results of the analysis revealed that psychological competence is an important component of professional pedagogical competence. At the same time, it was found
\end{abstract}

that the psychological competence of future Ukrainian language and literature teachers has not yet been the subject of dedicated scientific research.

For the purpose of a comprehensive study of psychological competence of future teachers-philologists the author proposed the definition of this phenomenon. The content and structure of the studied competence have been developed. It is proposed to distinguish motivational, cognitive, practical, personal and auto-psychological 
components. The content of each component is described in detail.

For further experimental work on the psychological competence formation of future Ukrainian language and literature teachers it was proposed to determine the criterial apparatus for evaluating its formation among students. Scientific approaches to the evaluation of various aspects of competence of future specialists were analyzed and summarized.

It has been established that the majority of researchers propose to distinguish motivational, cognitive, activity and personal evaluation criteria. Taking into consideration the necessity of correspondence of evaluation criteria to the structure of psychological competence, the criterial research apparatus was developed. It includes motivational and personal, cognitive, practical and auto-psychological criteria. For each criterion, the system of indicators corresponding to the content of the psychological competence structural components of future Ukrainian language and literature teachers is defined. Taking the developed criteria and indicators into account, high, average and low levels of psychological competence of the future Ukrainian language and literature teachers were highlighted and characterized.

Key words: professional pedagogical competence, psychological competence, future Ukrainian language and literature teachers, criterial apparatus of research, criteria, psychological competence indicators and levels.

Постановка проблеми. Актуальність обраної нами теми обумовлена необхідністю адекватної відповіді на виклики, що висуває сучасний соціум до сфери освіти. Ускладнення та розширення змісту програм загальної середньої освіти, запровадження нових форм навчання (дистанційної, змішаної, інклюзивної тощо), підвищення вимог до майбутніх фахівців, передусім щодо їхньої готовності швидко адаптуватися до змін у змісті та організації освітнього процесу, оволодівати новими сучасними технологіями навчання, працювати в класах, різнорідних за складом та рівнем підготовки, здійснювати позитивну комунікацію з учнями, колегами, адміністрацією, виявляти ініціативу i творчий підхід у роботі, здійснювати гармонійне виховання та всебічний розвиток учнів, сприяти збереженню їхнього фізичного та психічного здоров'я тощо, - усе це вимагає від сучасного викладача, зокрема й української мови та літератури, як сформованості високого рівня професійної компетентності, так і ii психологічної складової.

Аналіз наукових досліджень і публікацій. Зауважимо, що більшість дослідників, які присвятили свої наукові розвідки вивченню професійної педагогічної компетентності (А. Маркова, I. Зимня, І. Коновальчук, Н. Кузьміна, С. Максимюк, О. Овчарук, О. Пометун, Л. Штефан та ін.), виокремлюють у її складі психологічну складову. Це пояснюється тим, що професія педагога передбачає постійне педагогічне спілкування. Зокрема, психологічну компетентність учителя науковці трактують по-різному: як інтегровану характеристику рівня професійної підготовленості педагога, що базується на фундаментальних психолого-педагогічних знаннях і вироблених комунікативних уміннях, які проявляються в єдності з особистісними якостями (Казаннікова, 2012); як систему знань, умінь і навичок, що забезпечують майбутньому фахівцеві не тільки загальнопсихологічну підготовленість, а й високий рівень професійної самосвідомості, вміння керувати своїм психічним станом, сукупність психологічних знань і вмінь, а також особистісних якостей, які дозволяють ефективно здійснювати педагогічну діяльність (Рамзані, 2014); як здатність особистості до самопізнання, самоконтролю, ефективного спілкування і взаємодії 3 іншими людьми, саморозвитку та самореалізації (Бакаленко, 2018) тощо.

Базуючись на окреслених вище наукових позиціях, у попередніх наших дослідженнях було розпочато вивчення феномена психологічної компетентності майбутніх викладачів української мови та літератури й сформульовано ії визначення як «сталої підструктури професійно-педагогічної свідомості й самосвідомості особистості педагога, що формується на основі синтезу теоретичних і практичних психологічних знань, умінь, навичок і разом з іншими складовими професійно-педагогічної компетентності забезпечує його здатність успішно вирішувати завдання фахової діяльності» (Кошелева, 2019). Зокрема, ми запропонували власне бачення змісту та структури досліджуваної компетентності, до якої було включено мотиваційну, когнітивну, практичну, особистісну й аутопсихологічну складові, зміст яких докладно представлено у згаданій вище роботі.

Із метою подальшого розроблення технологій формування психологічної компетентності майбутніх викладачів української мови та літератури слід визначити критерії та показники іiї сформованості, що й обумовило написання нами означеного дослідження.

Мета статті - визначити й обгрунтувати критерії та показники сформованості психологічної компетентності майбутніх викладачів української мови та літератури у закладі вищої освіти.

Виклад основного матеріалу дослідження. Великий тлумачний словник сучасної української мови (2005) формулює поняття «критерій» як «підставу для оцінки, визначення або класифікацію чогось; мірило» (Великий тлумачний словник сучасної української мови, 2005, с. 588). Однак для визначення критеріального апарату нашої роботи доречно проаналізувати погляди науковців, які досліджували питання сформованості різних аспектів компетентності майбутніх фахівців.

Так, Л. Адарюкова, вивчаючи процес формування самоосвітньої компетентності майбутніх фахівців із кібербезпеки, пропонує діагностувати іiї за такими критеріями: особистісний (гуманістична спрямованість, мотиви професійного саморозвитку, установки на самоосвітню діяльність); прагматичний (знання та вміння у сфері самоосвіти); організаційний (здатність здійснювати самоосвіту); рефлексивний (навички самоаналізу, самоконтролю та самокорекції в самоосвітній діяльності) (Адарюкова, 2018).

Г. Піскурська з метою визначення сформованості професійної плюрилінгвальної компетентності у майбутніх менеджерів зовнішньоекономічної діяльності пропонує такі критерії та показники: мотиваційно-ціннісний 
(наявність потреб, мотивів щодо формування професійної плюрилінгвальної компетентності та усвідомлення іiї цінності); когнітивно-діяльнісний (лінгвістичні знання, готовність до роботи в полікультурному середовищі); рефлексивно-особистісний (здатність до рефлексії, сукупність професійно значущих якостей) (Піскурська, 2016).

М. Морозова у своїй дисертаційній роботі, присвяченій проблемі формування економічної компетентності у студентів гуманітарних спеціальностей, виокремлює такі критерії оцінювання досліджуваної компетентності: когнітивно-інформаційний (рівень теоретичних знань, розвиток економічного мислення, загальна інформаційна культура); мотиваційно-ціннісний (потреба в економічній діяльності, особистісна цінність економічної компетентності, прагнення до самоосвіти та самовиховання); особистісно-діяльнісний (особистісні якості та лідерські здібності, базові економічні вміння й навички, досвід економічної діяльності) (Морозова, 2018).

Таким чином, більшість науковців, визначаючи критерії оцінювання сформованості досліджуваних компетентностей, передбачають виокремлення таких аспектів: мотиваційний, когнітивний, діяльнісний, особистісний.

При розробленні власного критеріального апарату ми враховували не лише проаналізовані вище позиції, а й те, що критерії та показники сформованості психологічної компетентності майбутніх викладачів української мови та літератури мають охоплювати всі iii структурно-змістові характеристики, що забезпечить об'єктивність оцінювання. Зважаючи на це, критеріальний апарат нашого дослідження матиме таку структуру (див. табл. 1).

\section{Критеріальний апарат оцінювання психологічної компетентності майбутніх викладачів української мови та літератури}

\begin{tabular}{|c|c|}
\hline Критерії & Показники \\
\hline $\begin{array}{c}\text { Мотиваційно- } \\
\text { особистісний }\end{array}$ & $\begin{array}{l}\text { Мотиви формування власної психологічної компетентності; прагнення щодо формування психо- } \\
\text { логічної культури учнів, збереження і зміцнення їхнього психологічного здоров'я, встановлення } \\
\text { ефективної та позитивної педагогічної комунікації; інтерес до психологічних знань, до досліджень } \\
\text { психічних процесів та явищ; здатність до емпатії, співчуття, психологічно обгрунтованого вирішення } \\
\text { педагогічних завдань і проблем, конструктивного розв’язання конфліктів на основі психологічних } \\
\text { знань }\end{array}$ \\
\hline Когнітивний & $\begin{array}{l}\text { Сформованість фахових знань про: } \\
\text { - факти, закономірності та механізми психіки, вікові й індивідуальні особливості розвитку людини; } \\
\text { - психологічні відмінності школярів та їхні джерела; } \\
\text { - психологічні закономірності навчання й виховання, особливості педагогічної діяльності; } \\
\text { - психологічні компоненти спілкування людей, міжособистісні та внутрішньоособистісні конфлікти; } \\
\text { - теоретичні та практичні аспекти збереження і зміцнення психічного здоров’я учнів; } \\
\text { - методи і засоби проведення психолінгвістичного та літературознавчого аналізу художніх текстів; } \\
\text { - особливості психологічного впливу мовних засобів та мовленнєвих структур у різних типах дис- } \\
\text { курсу на учнів }\end{array}$ \\
\hline Практичний & $\begin{array}{l}\text { Сформованість фахових умінь: } \\
\text { - розробляти й запроваджувати науково обгрунтовані з позицій вікової, педагогічної психології, } \\
\text { психології основ мовленнєвої діяльності, психолінгвістики інноваційні технології навчання на уроках } \\
\text { української мови та літератури; } \\
\text { - здійснювати разом з учнями психолінгвістичний та літературознавчий аналіз художніх текстів, } \\
\text { базуючись на комплексних знаннях із різних галузей психології, лінгвістики та літературознавства; } \\
\text { - спираючись на сукупність психологічних знань, розкривати учням багатство й індивідуальні осо- } \\
\text { бливості внутрішнього світу письменників та його відображення у творах, що вивчаються; } \\
\text { - формувати вміння учнів здійснювати аналіз соціально-психологічного досвіду та індивідуаль- } \\
\text { но-психологічних особливостей персонажів художніх творів; } \\
\text { - пояснювати учням психологічне підгрунтя поведінки та стосунків персонажів у літературних } \\
\text { творах зі шкільної програми; } \\
\text { - установлювати на уроках української мови та літератури сприятливу, довірливу атмосферу у ході } \\
\text { обговорення психологічних особливостей сприйняття художніх текстів; } \\
\text { - формувати в учнів навички самоаналізу, саморефлексії та самокорекції власної поведінки шляхом } \\
\text { формування базових психологічних знань у процесі підготовки творів-роздумів }\end{array}$ \\
\hline Аутопсихологічний & $\begin{array}{l}\text { Сформованість особистих умінь: } \\
\text { - здійснювати самоаналіз, саморефлексію, саморегуляцію власної поведінки і дій; } \\
\text { - використовувати психопрофілактичні методики, спрямовані на боротьбу зі стресами та емоційним } \\
\text { вигоранням }\end{array}$ \\
\hline
\end{tabular}


Запропоновані вище критерії та показники є підставою для характеристики рівнів сформованості психологічної компетентності майбутніх викладачів української мови та літератури (див. табл. 2).

Таблиия 2

\section{Характеристика рівнів сформованості психологічної компетентності майбутніх викладачів української мови та літератури}

\begin{tabular}{|c|c|}
\hline Рівні & Характеристика рівнів \\
\hline Високий & $\begin{array}{l}\text { Виявлення стійких внутрішніх мотивів та інтересів до набуття психологічних знань і їхнього використання в } \\
\text { педагогічній діяльності, здатності до ефективного безконфліктного спілкування в освітньому процесі; воло- } \\
\text { діння системними, глибокими знаннями з різних галузей психології; здатність використовувати їх у практиці } \\
\text { педагогічної діяльності для вирішення як стандартних, так і нетипових навчальних, виховних і розвивальних } \\
\text { завдань; виявлення професійної, врівноваженої, продуманої поведінки на уроках і позакласних заходах під } \\
\text { час педагогічних практик }\end{array}$ \\
\hline Середній & $\begin{array}{l}\text { Наявність мотивів отримання психологічних знань, усвідомлення їхньої важливості для життєдіяльності лю- } \\
\text { дини; володіння достатнім обсягом психологічних знань; здатність використовувати їх у практиці педагогічної } \\
\text { діяльності для вирішення стандартних навчальних, виховних і розвивальних завдань; виявлення здатності до } \\
\text { самоконтролю власної поведінки в типових ситуаціях освітнього процесу }\end{array}$ \\
\hline Низький & $\begin{array}{l}\text { Недостатня мотивація щодо набуття психологічних знань, ставлення до них як до другорядних у професійній } \\
\text { діяльності вчителя; володіння несистемними знаннями } 3 \text { психології; нездатність усвідомлено та системно } \\
\text { використовувати їх у практиці педагогічної діяльності; недостатній рівень саморефлексії, самоконтролю та } \\
\text { стресостійкості, продемонстрований під час педагогічних практик }\end{array}$ \\
\hline
\end{tabular}

Таким чином, нами було визначено критерії, показники та рівні оцінювання психологічної компетентності майбутніх викладачів української мови та літератури, що базуються на змістовних характеристиках і1і компонентів, а отже, дають змогу зробити обгрунтовані висновки про ступінь сформованості досліджуваної компетентності як цілісного явища.

Висновки. У статті вирішено важливе наукове завдання щодо розроблення критеріального апарату оцінювання психологічної компетентності майбутніх викладачів української мови та літератури як значущої складової їхньої професійної компетентності. Відповідно до змістовно-структурних характеристик психологічної компетентності, визначених у попередніх дослідженнях, нами запропоновано використовувати такі критерії оцінювання іiї сформованості, як мотиваційно-особистісний, когнітивний, практичний та аутопсихологічний. У межах кожного критерію нами було визначено перелік показників сформованості відповідних компонентів психологічної компетентності в майбутніх викладачів української мови та літератури. На підставі виконаних розробок виокремлено та схарактеризовано високий, середній та низький рівні сформованості означеної компетентності, що дає можливість подальшого науково обгрунтованого проведення дослідно-експериментальної роботи щодо формування психологічної компетентності в майбутніх викладачів української мови та літератури.

Перспективи подальших досліджень. Нашу подальшу роботу плануємо спрямувати на розроблення експериментальної технології діагностики та формування всіх компонентів психологічної компетентності майбутніх викладачів української мови та літератури на підставі розробленого критеріального апарату.

\section{СПИСОК ВИКОРИСТАНОЇ ЛІТЕРАТУРИ}

Казаннікова, О. В. (2012). Психологічна компетентність педагога. URL: http://sworld.com.ua/ konfer29/1200.pdf (дата звернення: 17.06.2021).

Рамзані, Е. В. (2014). Сутність поняття психологічної компетентності вчителя. Духовність особистості: методологія, теорія і практика. Сєвєродонецьк: СНУ ім. В. Даля. № 2 (61). С. 158-165.

Бакаленко, О. А. (2018). Психологічна компетентність як ключова компетентність сучасного фахівця. Вісник Харківського національного університету ім. В. Н. Каразіна. Серія "Теорія культури і філософія науки». Харків: ХНУ ім. В. Н. Каразіна. Вип. 58. C. $132-138$.

Кошелева, Н. Г. (2019). Визначення змісту і структури психологічної компетентності майбутніх викладачів української мови і літератури. Молодий вчений. № 10 (74). С. 547-551.

Великий тлумачний словник сучасної української мови. (2005) / уклад. та гол. ред. В. Т. Бусел. Київ; Ірпінь: Перун. 1728 с.

Адарюкова, Л. Б. (2018). Формування самоосвітньої компетентності майбутніх фахівців з кібербезпеки у технічних університетах: автореф. дис. ... канд. пед. наук: 13.00.04 / Луганський національній університет імені Тараса Шевченка. Старобільськ. 20 с.

Піскурська, Г. В. (2016). Формування професійної плюрилінгвальної компетентності майбутніх менеджерів зовнішньоекономічної діяльності у вищому технічному навчальному закладі: автореф. дис. ... канд. пед. наук: 13.00.04 / Луганський національній університет імені Тараса Шевченка. Старобільськ. 20 с.

Морозова, М. М. (2018). Формування економічної компетентності у студентів гуманітарних спеціальностей у навчально-виховному процесі ВНЗ: дис. ... канд. пед. наук: 13.00.04 / Луганський національній університет імені Тараса Шевченка. Старобільськ. 312 с. 


\section{REFERENCES}

Kazannikova, O. V. (2012). Psykholohichna kompetentnist pedahoha [Psychological competence of the teacher]. URL: http://sworld.com.ua/konfer29/1200.pdf (data zvernennya: 17.06.2021). [in Ukrainian].

Ramzani, E. V. (2014). Sutnist poniattia psykholohichnoi kompetentnosti vchytelia [The Essence of psychological Competence of a Teacher]. Dukhovnist osobystosti: metodolohiia, teoriia i praktyka. Sievierodonetsk: SNU im. V. Dalia. № 2 (61). S. 158-165. [in Ukrainian].

Bakalenko, O. A. (2018). Psykholohichna kompetentnist yak kliuchova kompetentnist suchasnoho fakhivtsia [Psychological Competence as the key Competence of the modern Specialist]. Visnyk Kharkivskoho natsionalnoho universytetu im. V. N. Karazina. Seriia «Teoriia kultury i filosofiia nauky». Kharkiv: KhNU im. V. N. Karazina. Vyp. 58. S. 132-138. [in Ukrainian].

Kosheleva, N. H. (2019). Vyznachennia zmistu i struktury psykholohichnoi kompetentnosti maibutnikh vykladachiv ukrainskoi movy i literatury [Determining the content and structure of psychological competence of future ukrainian language and literature teachers]. Molodyi vchenyi. № 10 (74). S. 547-551. [in Ukrainian].

Velykyi tlumachnyi slovnyk suchasnoi ukrainskoi movy [Large explanatory dictionary of the modern Ukrainian language]. (2005). Kyiv; Irpin: Perun. 1728 s. [in Ukrainian].
Adariukova, L. B. (2018). Formuvannia samoosvitnoi kompetentnosti maibutnikh fakhivtsiv z kiberbezpeky u tekhnichnykh universytetakh [Formation of self-educational competence of future cybersecurity specialists in technical universities]: avtoref. dys. ... kand. ped. nauk: 13.00.04. / Luhanskyi natsionalnii universytet imeni Tarasa Shevchenka. Starobilsk. 20 s.

Piskurska, H. V. (2016). Formuvannia profesiinoi pliurylinhvalnoi kompetentnosti maibutnikh menedzheriv zovnishnoekonomichnoi diialnosti u vyshchomu tekhnichnomu navchalnomu zakladi [Formation of professional plurilingual competence of future managers of foreign economic activity in a higher technical educational institution]: avtoref. dys. ... kand. ped. nauk: 13.00.04. / Luhanskyi natsionalnii universytet imeni Tarasa Shevchenka. Starobilsk. $20 \mathrm{~s}$.

Morozova, M. M. (2018). Formuvannia ekonomichnoi kompetentnosti u studentiv humanitarnykh spetsialnostei u navchalno-vykhovnomu protsesi VNZ [Formation of economic competence in students of humanities in the educational process of higher education]: dys. kand. ped. nauk / Luhanskyi natsionalnii universytet imeni Tarasa Shevchenka. Starobilsk. 312 s.

Дата надходження до редакиіï: 18.06.2021 p. 